Conclusion: Findings indicate a significantly greater one-year treatment effect of analgesic use that lowered pain severity in persons with or atrisk for symptomatic knee OA who also had depression. Thus, knee OA patients with depression may derive more benefit from analgesic treatment for chronic pain than non-depressed patients, perhaps because their pain is undertreated in routine clinical practice.

Acknowledgement: This study was supported by the Rheumatology Research Foundation's Scientist Development Award.

Disclosure of Interests: Alan Rathbun: None declared, Michelle Shardell: None declared, Joseph Gallo: None declared, Alice Ryan: None declared, Elizabeth Stuart: None declared, Megan Schuler: None declared, Michelle Yau: None declared, Marc Hochberg Shareholder of: BriOri Biotech, Theralogix LLC., Consultant for: Bristol Myers Squibb, Eli Lilly, EMD Serono, Novartis Pharma AG, Pfizer Inc., Samumed LLC, Symic Bio Inc., Theralogix LLC, TissueGene Inc., TLC Biopharmaceuticals, Inc., Zynerba, Galapagos, IQVIA, Hoffman LaRoche.

DOI: 10.1136/annrheumdis-2019-eular.7719

\section{THU0450 QUALITY OF LIFE OF PATIENTS WITH A COMBINATION OF SARCOPENIA AND OSTEOARTHRITIS OF LOWER EXTREMITY}

Yuliya Safonova ${ }^{1}$, Evgeniy Zotkin ${ }^{2} .{ }^{1}$ Northwestern State Medical University named after I.I. Mechnikov, St. Petersburg, Russian Federation; ${ }^{2}$ Research Institute of Rheumatology named after V.A. Nasonova, Moscow, Russian Federation

Background: In accordance with the updated recommendations of the EWGSOP (2018), sarcopenia is a muscle disease (muscle failure) rooted in adverse muscle changes that accrue across a lifetime [1]. Sarcopenia and osteoarthritis significantly affect the self-esteem quality of life which is associated with a decrease in muscle strength and muscle performance, falls, joint pain [2]. In 2015, the SarQoL ${ }^{\circledR}$ questionnaire (Sarcopenia and Quality of Life, www.sarqol.org) was developed, specific to patients with sarcopenia. Improvement of quality of life should be the priority of any interventions to prevent and treat osteoarthritis and sarcopenia in the ageing population [3].

Objectives: Perform quality of life analysis in patients with osteoarthritis and sarcopenia.

Methods: Prospective study of 159 women, mean age $74 \pm 13.3$. Sarcopenia was diagnosed according to the algorithm proposed by the European Working Group on Sarcopenia in Older People (EWGSOP, 2010). Life quality assessment was performed using EQ-5D questionnaires and a specific questionnaire in patients with sarcopenia SarQoL.

Results: $31.45 \%$ of people with OA older than 65 years had sarcopenia. The results of the study showed a statistically significant decrease in overall health on the questionnaire EQ-5D in patients with sarcopenia compared with patients without sarcopenia $(0.48 \pm 0.22$ points and 0.74 \pm 0.27 points, respectively, $p<0.01$ ) and no differences according to the EQ-VAS scale in the studied groups $(p>0.05)$. The decrease in the general health status of EQ-5D in patients with OA sarcopenic compared with non-sarcopenic is associated with a restriction of the usual daily activities: in $70 \%(95 \% \mathrm{Cl}: 55.4-82.1)$ and $52.3 \%(95 \% \mathrm{Cl}: 42.5-61.9)$ respectively, $(p<0.01)$. In patients with $O A$, reduced global SarQoL in sarcopenic subjects compared to non-sarcopenic ones: $50,65 \pm 14,23$ vs. $75,10 \pm 14,46, \quad p<0,001$. Significantly lower scores for all domains were found in patients with OA sarcopenic compared with non-sarcopenic patients $(p<0.001)$

Conclusion: In patients with $O A$ sarcopenic, the quality of life is worse than that of non-sarcopenic due to a decrease in habitual daily activities, probably associated with low muscle strength.

\section{REFERENCES:}

[1] Cruz-Jentoft AJ, Bahat G, Bauer J, et al. Guidelines. Sarcopenia: revised European consensus on definition and diagnosis on definition and diagnosis. Age and Ageing 2018; 0: 1-16. doi: 10.1093/ageing/afy169Milte R, Crotty M. Musculoskeletal health, frailty and functional decline. Best Pract Res Clin Rheumatol. 2014;28(3):395-410

[2] Beaudart C., Biver E., Bruyère O. et al. Assessment of Quality of Life in Musculo-Skeletal Health. Aging Clin Exp Res. 2018 May; 30(5): 413418Hoops ML, Rosenblatt NJ, Hurt CP, Crenshaw J, Grabiner MD. Does lower extremity osteoarthritis exacerbate risk factors for falls in older adults? Womens Health (Lond Engl). 2012;8(6):685-96

[3] Beaudart C, Biver E, Reginster J-Y, et al. Development of a self-administrated quality of life questionnaire for sarcopenia in elderly subjects: the SarQoL. Age Ageing. 2015; 44 (6):960-6

Disclosure of Interests: None declared
DOI: 10.1136/annrheumdis-2019-eular.3179

\section{THU0451 CHONDROITIN SULFATE USE AND INCIDENCE OF CANCER: A LONGITUDINAL ANALYSIS OF THE OSTEOARTHRITIS INITIATIVE DATA}

Ivan Shirinsky, Valery Shirinsky. FEDERAL STATE BUDGETARY SCIENTIFIC INSTITUTION «RESEARCH INSTITUTE OF FUNDAMENTAL AND CLINICAL IMMUNOLOGY» (RIFCI), Laboratory of Clinical Immunopharmacology,

Novosibirsk, Russian Federation

Background: Chondroitin sulfate (CS) is widely used nutritional supplement for the treatment of osteoarthritis. There is growing in vitro evidence that CS may play a role in oncogenesis and metastasis of several solid tumors including melanoma [1] and breast cancer [2]. The data evaluating pro-oncogenic effects of CS in humans are lacking.

Objectives: To assess influence of CS use on incidence of cancer.

Methods: For the current study we used 6-year longitudinal data obtained from the Osteoarthritis Initiative (OAI) progression $(n=1390)$ and incidence $(n=3284)$ subcohorts, which are publically available at https://oai. nih.gov. To reduce the risk of bias, only participants who did not take CS at baseline were included in the analysis (a "new-user" design). Incident cancer was defined as an occurrence of self-reported cancer, other than skin cancer, leukemia or lymphoma. The information on self-reported cancer was collected from the Charlson Comorbidity Index. CS users with cancer were defined using the following criteria (1) a person who used CS for at least 6 months (2) chondroitin use was at least 1 year before the incident self-reported cancer. For CS users without a cancer the duration of CS use had to be at least 6 months. All other participants were classified as non-users. To examine the cancer risk for CS users compared with non-users, we calculated the incidence rate ratios (IRRs), adjusting for age (2-year age groups), using the Mantel-Haenszel test.

Results: A total of 3167 participants neither having cancer nor taking CS at baseline were included in the analysis. There were $570(21.95 \%)$ new users of CS. We identified $160(6.2 \%)$ and $37(6.5 \%)$ cases of incident self-reported cancer in the non-users and users groups, respectively. The adjusted IRR for the association between CS use and cancer was 0.22 $(95 \% \mathrm{Cl} 0.77-1.62)$ which was not statistically significant $(p=0.64)$.

Conclusion: CS use was not associated with excess overall incidence of self-reported cancers. Nonetheless, given the strong in vitro evidence of CS pro-oncogenic effects on several types of tumors there is a need for further epidemiological data evaluating CS effects on specific kinds of cancer

\section{REFERENCES :}

[1] Lin R, Xia S, Shan C, Chen D, Liu Y, Gao X, Wang M, Kang HB, Pan Y, Liu S, et al: The Dietary Supplement Chondroitin-4-Sulfate Exhibits Oncogene-Specific Pro-tumor Effects on BRAF V600E Melanoma Cells. Mol Cell 2018, 69(6):923-937 e928.

[2] Cooney CA, Jousheghany F, Yao-Borengasser A, Phanavanh B, Gomes T, Kieber-Emmons AM, Siegel ER, Suva LJ, Ferrone S, Kieber-Emmons $\mathrm{T}$, et al: Chondroitin sulfates play a major role in breast cancer metastasis: a role for CSPG4 and CHST11 gene expression in forming surface $\mathrm{P}$. selectin ligands in aggressive breast cancer cells. Breast Cancer Res 2011, 13(3):R58.

Disclosure of Interests: None declared

DOI: 10.1136/annrheumdis-2019-eular.1398

\section{THU0452 PREVALENCE OF AXIAL OSTEOARTHRITIS IN SPAIN: EPISER-2016}

Maite Silva-Díaz ${ }^{1}$, Víctor Quevedo Vila², Daniel Seoane Mato ${ }^{3}$,

Sagrario Bustabad ${ }^{4}$, Francisco J. Blanco ${ }^{1}$, Grupo de Trabajo Proyecto Episer2016 ${ }^{3}$. ${ }^{1}$ Complexo Hospitalario Universitario A Coruña, Instituto de investigación biomédica A Coruña (INIBIC), A Coruña, Spain; ${ }^{2}$ Hospital Comarcal de Monforte de Lemos, Lugo, Lugo, Spain; ${ }^{3}$ Unidad de Investigación, Sociedad Española de Reumatología, Madrid, Spain; ${ }^{4}$ Hospital Universitario de Canarias, Canarias, Spain

Background: Osteoarthritis $(O A)$ is a heterogeneous group of diseases with common clinical and radiographic manifestations involving the peripheral and axial skeletal. $\mathrm{OA}$ is the most prevalent rheumatic disease how ever, there are very few publications focused in axial OA. In 2016, the Spanish Society of Rheumatology (SER) started a population descriptive study (EPISER 2016) to analyze the prevalence of 13 rheumatic diseases 